\title{
Characterization of $\beta$-Galactosidase from Lactose Utilizing Yeast Isolated from the Dairy Sample
}

\author{
Bivek Dahal ${ }^{1 \#}$, Sujan Karki ${ }^{1 \#}$, Nabaraj Adhikari ${ }^{2}$, Upendra Thapa Shrestha ${ }^{2,3}$ \\ ${ }^{1}$ Universal Science College, Pokhara University, Baneshwor, Kathmandu \\ ${ }^{2}$ Central Department of Microbiology, Tribhuvan University, Kirtipur, Kathmandu \\ ${ }^{3}$ Research Laboratory for Biotechnology and Biochemistry (RLABB), Kathmandu \\ \# Both the authors have equal contributions.
}

Corresponding author: Upendra Thapa Shrestha, Central Department of Microbiology, Tribhuvan University, Kirtipur, Kathmandu. Email: upendra.thapashrestha@cdmi.tu.edu.np

\begin{abstract}
Objectives: The objective of the study was to isolate lactose positive yeasts from dairy samples collected from local markets of Kathmandu, to extract crude $\beta$-galactosidase from the lactose positive yeast and to characterize the enzyme for optimum time duration, $\mathrm{pH}$, temperature, MichaelisMenten constant $\left(\mathrm{K}_{\mathrm{m}}\right)$ and maximum activity $\left(\mathrm{V}_{\max }\right)$.

Methods: Four lactose positive yeast strains were isolated from dairy samples collected from local market of Kathmandu by pour plate method. Single strain having maximum lactose positive activity was selected for the study. The mass culture of the lactose positive yeast strain was lysed by $2 \%$ Chloroform and the yeast cell lysate containing $\beta$-galactosidase (i.e. crude enzyme extract) was characterized by using ONPG (Ortho-Nitrophenyl- $\beta$-D-galactopyranoside) as substrate. ONPG is a colorless substrate for the enzyme assay which is hydrolyzed by the enzyme into yellow colored product ONP (Ortho-Nitrophenol). The concentration of product formed was monitored spectrophotometrically at $420 \mathrm{~nm}$ to determine the enzyme activity and to characterize the enzyme. Results: The enzyme had wide range of working temperature from $0-50^{\circ} \mathrm{C}$, with optimal temperature of $37^{\circ} \mathrm{C}$. However, greater than $50 \%$ hydrolyzing ability was maintained in the range of $14-40^{\circ} \mathrm{C}$. Optimum time of reaction was $70 \mathrm{~min}$. The enzyme had maximum activity in the near neutral $\mathrm{pH}$ of 6.8. Michaelis-Menten constant of the enzyme was found to be $2.23 \mathrm{mM}$ of ONPG and $\mathrm{V}_{\max }$ was 58.82 $\mathrm{nmol} / \mathrm{min} / \mathrm{ml}$. Enzyme activity was $27.88 \mathrm{nmol} / \mathrm{min} / \mathrm{ml}$, Specific enzyme activity was $59.97 \mathrm{nmol} /$ $\mathrm{min} / \mathrm{mg}$ and total enzyme activity was $3346.33 \mathrm{nmol} / \mathrm{min}$.
\end{abstract}

Conclusion: The activity over a wide range of temperature $0-50^{\circ} \mathrm{C}$ with low $\mathrm{K}_{\mathrm{m}}$ value shows that the enzyme has a commercial application in clearance of lactose pollution in waste water in different environmental conditions.

Keywords: Yeast, $\beta$-galactosidase, enzyme activity, ONPG, Km

\section{INTRODUCTION}

$\beta$-galactosidase (E.C.3.2.2.1.23), also called beta-gal or $\beta$-gal, is a hydrolase enzyme that catalyses hydrolysis of beta-galactosides into monosaccharides. It is an exoglycosidase which hydrolyses the $\beta$-glycosidic bond formed between a galactose and its organic moiety. Substrates for different $\beta$-galactosidases include ganglioside GM1, lactosylceramides, lactose and

Date of Submission: September 15, 2020

Published Online: December, 2020 various glycoproteins. It may also cleave fucosides and arabinosides with much lower efficiency. $\beta$ -galactosidase catalyzes the hydrolysis of lactose, abundant disaccharide in milk to monosaccharides; glucose and galactose (Husain 2010). $\beta$-galactosidase hydrolyses the $\beta-1,4-\mathrm{D}$-galactosidic linkage of lactose, as well as those of related chromogens, O-nitro-phenyl$\beta$-D-galactopyranoside (oNPG), $\quad$-nitrophenyl- $\beta$-D
Date of Acceptance: October 17, 2020

DOI: https:/ / doi.org/10.3126/tujm.v7i0.33874 
galactopyranoside (PNPG) and 6-bromo-2-naphthylgalacto pyranoside (BNG) (Mahoney 1998).

Glycoside hydrolases $\left(\mathrm{GH}_{\mathrm{s}}\right)$ including $\beta$-galactosidase constitute 113 protein families (Cantarel et al. 2009). Lactose degrading $\beta$-galactosidases (lactases) are classified as GH2 family and others are classified as GH42 family which shows activity towards $\beta$-galactosyl linkages in oligosaccharides (Hinz et al. 2004; Shipkowski et al. 2006). Lactase is often confused as an alternative name for $\beta$-galactosidase, but it is actually simply a sub-class of $\beta$-galactosidase.

Some $\beta$-galactosidases may also have an activity of transferring one or more, D-galactosyl units onto lactose (Rabiu et al. 2001). This enzymatic property is called transgalactosylation which is potential for the production of GOS (Galacto-oligosaccharides) (Miller and Whistler 2000).

$\beta$-galactosidase is an important enzyme in food, pharmaceutical industries and also in waste management. $\beta$-galactosidase can be used to avoid problems of lactose intolerance in individuals who are deficient in lactase. Lactose intolerance is a common problem prevalent in more than half of the world's population (Amir and Whorwell 2009; Johnson et al. 1993; Suarez and Savaiano 1997). High lactose content in non-fermented, sweetened, condensed and frozen dairy products such as ice-cream and condensed milk can lead to excessive lactose crystallization resulting in products with mealy, sandy or gritty texture (El-Kader etal.2012). Thus $\beta$-galactosidase can be used to avoid the crystallization of lactose in sweetened, condensed and frozen dairy products. This helps to improve sweetness and to increase the solubility of milk products (Kara, 2004). It can be used to manage biodegradable wastes of food, dairy and beverage industries. Lactose is one of the major components of whey in cheese industry that is non-friendly in environment. Whey is the relatively clear supernatant that remains after the coagulated casein is separated from the milk for cheese making. Its lactose content is 4.5 to $5 \%$ (Nahvi and Moeini 2004). GOS are non-digestible oligosaccharides comprised of 2-20 molecules of galactose and 1 molecule of glucose (Miller and Whistler 2000). GOS are recognized as prebiotics since, they can stimulate the proliferation of lactic acid bacteria and Bifidobacteria in human intestine (Sako et al. 1999) [15]. So, much attention has been given to the production of GOS, especially via enzymatic transgalactosylation, since the chemical synthesis is very tedious (Sears and Wong 2001).

$\beta$-galactosidases are widely distributed in numerous biological systems e.g. Plant and animal tissues, microorganisms (Fungi-yeasts and molds, actinomycetes) (Zadow 1992). Compared to the animal and plant sources of the enzyme, microorganisms produce enzyme at higher yields and thus lower the price of commercial $\beta$-galactosidase production (Santos et al. 1998). Thus, for large scale commercial production of the enzyme much work is focused on microbial production. The characteristics of the enzyme vary depending on its source. In general, $\beta$-galactosidase from yeasts and bacteria have optimum $\mathrm{pH}$ near neutral range (6.5-7) whereas the enzyme from molds act better at acidic range (3-5) (Wierzbicki and Kosikowski 1973).

The most studied $\beta$-galactosidase is the one produced by Escherichia coli but due to possible toxic factor associated with the coliform, the crude isolate of $\beta$-galactosidase is unlikely to be used in food processes (Santos et al. 1998). Therefore, $\beta$-galactosidases used in industrial scale for the production of milk and dairy products are isolated from microorganisms with GRAS status (generally recognized as safe). The commercial $\beta$-galactosidase are generally extracted from yeasts $(K$. lactis and K. fragalis) and fungi (Aspergillus niger and $A$. oryzae) (Harju 1987).

So far, no studies have been made on $\beta$-galactosidase extracted from lactose utilizing yeasts isolated from dairy samples in Nepal. Hence, we aimed to characterize $\beta$-galactosidase extracted from lactose utilizing yeasts isolated from dairy samples collected from local market of Kathmandu valley and evaluated the potential applications of enzymes in clearance of lactose pollution in waste water.

\section{MATERIALS AND METHODS}

Isolation: Eight different dairy samples were collected from different dairies in Kathmandu valley (4 yoghurt samples, 2 milk samples and 2 cotton cheese/farmer cheeses/paneer samples). 1gm of each dairy sample was taken for serial dilution upto $10^{-5} .100 \mu \mathrm{l}$ of dilutions $\left(10^{-2} 10^{-4}, 10^{-5}\right)$ were spread on YGCA Plates $(5 \mathrm{gm}$ Yeast extract, 20 gm Glucose, 0.1 gm Chloramphenicol in 1 liter of distilled water) and incubated at $25^{\circ} \mathrm{C}$ for $72 \mathrm{hrs}$. Yeast colonies with distinct morphological differences were selected and then purified by streaking on PDA plates and stored at $4^{\circ} \mathrm{C}$ (Nahvi and Moeini 2004). 
Sugar assimilation test: Sugars used were Glucose, Fructose, Galactose, Sucrose, Lactose, Maltose, Raffinose, Xylose, Mannitol, and Dextrose. Sugar assimilation test was done using basal fermentative medium YEP Broth containing chloramphenicol (4.5 gm Yeast extract, 7.5 gm Peptone, 20 gm sugar (Raffinose $40 \mathrm{gm}$ ), Chloramphenicol $0.1 \mathrm{gm}$ per liter). The final working solution was made by addition of $4 \mathrm{ml}$ of Bromothymol blue stock solution (50 mg/75 $\mathrm{ml}$ in distilled water) to $100 \mathrm{ml}$ of basal fermentative medium. After sterilization by autoclaving, chloramphenicol was added to the basal media. $10 \mathrm{ml}$ of basal media was dispensed into sterile test tubes and test tubes were inoculated with yeast isolates and incubated at $25^{\circ} \mathrm{C}$ for $72 \mathrm{hrs}$. Test tubes were inspected at frequent intervals and positive sugar assimilation results were indicated by change in color of indicator from green to yellow. Control tubes were used in sets to monitor contamination. Lactose positive yeast isolates were identified from this test and these isolates were subjected to further study and mass culture (Nahvi and Moeini 2004).

Study of colonial and microscopic morphology: Colonial morphology of lactose positive yeast isolates on PDA plates such as color, pigmentation, consistency, elevation, shape, size, margin, opacity was studied. The microscopic morphology of the lactose positive yeast isolates was studied after gram staining (Barnett et al. 1990; Nahvi and Moeini 2004).

Mass culture: Mass culture of lactose positive yeast isolates was done in enrichment media YEP broth containing chloramphenicol (10 gm Yeast extract, $20 \mathrm{gm}$ Peptone, 20 gm Lactose, 0.1 gm Chloramphenicol per liter of distilled water). Yeast isolates were inoculated into $1000 \mathrm{ml}$ of sterile broth $(\mathrm{pH} 7.0)$ in sterile condition in a conical flask. The flask was then incubated in water bath shaker at $30^{\circ} \mathrm{C}$ for 48 hours (Nahvi and Moeini 2004).

Enzyme extraction: $1000 \mathrm{ml}$ YEP broth was centrifuged at $7000 \mathrm{rpm}$ for 10 minutes and resulting pellet of yeast cells was first washed with $20 \mathrm{ml}$ phosphate buffer ( $\mathrm{pH}$ $7.0,0.1 \mathrm{M}$ ) and then re-suspended in $120 \mathrm{ml}$ of phosphate buffer (pH 7.0, 0.1M). Chloroform ( $2 \% \mathrm{v} / \mathrm{v})$ was added to lyse the yeast cells and incubated overnight at $37^{\circ} \mathrm{C}$. Yeast lysate was then centrifuged at 10,000 rpm for 20 minutes. Supernatant was then collected. Supernatant is the crude enzyme extract (Nahvi and Moeini 2004).
Determination of protein concentration: Protein concentration was determined by Bradford method. In 6 test tubes working BSA solution $(1 \mathrm{mg} / \mathrm{ml}) 10,20$, $40,60,80,100 \mu 1$ was taken respectively. Volume was maintained to $200 \mu \mathrm{l}$ by addition of $\mathrm{PO}_{4}$ buffer $(\mathrm{pH}$ 7.0, 0.01M). $2300 \mu \mathrm{l}$ of Bradford reagent was added to each test-tubes and the final volume was $2500 \mu 1$. Absorbance was taken at $595 \mathrm{~nm}$ against the blank (200 $\mu \mathrm{l} \mathrm{PO}_{4}$ buffer and $2300 \mu \mathrm{l}$ Bradford reagent) after $5 \mathrm{~min}$ of incubation. Calibration curve was made for protein concentration Vs. absorbance. $40 \mu \mathrm{l}$ of test sample ( $\beta$-galactosidase extract) was taken in a test tube and volume was maintained to $200 \mu \mathrm{l}$ by addition of $\mathrm{PO}_{4}$ buffer. $2300 \mu 1$ of Bradford reagent was added and after $5 \mathrm{~min}$ of incubation absorbance was taken at $595 \mathrm{~nm}$. The concentration of the test sample was determined by comparing the absorbance of the sample with the calibration curve (Bradford 1976).

Preparation of enzyme substrate: (ONPG) OrthoNitrophenyl- $\beta$-D-galactopyranoside $\quad\left(0.01\right.$ molesL $\left.^{-1}\right)$ prepared in a phosphate buffer of $\mathrm{pH} 6.8$ was used as substrate for the $\beta$-galactosidase assay (Zhou and Chen 2001).

Determination of enzyme activity: $750 \mu$ l of substrate solution (ONPG) with $\mathrm{pH} 6.8$ and $250 \mu$ of crude enzyme extract were added in a test tube. $2 \mathrm{ml}$ of phosphate buffer ( $\mathrm{pH} 6.8,0.1 \mathrm{M}$ ) was added to the test tube and then incubated at $37^{\circ} \mathrm{C}$ for 70 minutes. The reaction was quenched by adding $250 \mu \mathrm{l} \mathrm{Na}_{2} \mathrm{CO}_{3}$ (0.5 moles $\left.\mathrm{L}^{-1}\right)$. Reaction progress was determined spectrophotometrically at $420 \mathrm{~nm}$ against the blank (750 $\mu \mathrm{l}$ ONPG, $2250 \mu \mathrm{l}$ phosphate buffer of $\mathrm{pH}$ 6.8) (Fernandes et al. 2002).

Enzyme activity was calculated by accordingly. Enzyme activity $=\frac{0 \text { D } 420 \times \text { Reaction Volume }}{0.0045 \times \text { Enzyme volume } \times \text { Time }}$

Specific enzyme activity $=\frac{0 \mathrm{D} 420 \times \text { Reaction Volume }}{0.0045 \times \text { Enzyme volume } \times \text { Time } \times \text { protein concentration }}$

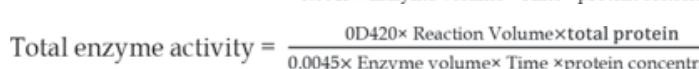

Determination of optimum time duration: 10 test tubes were filled with $750 \mu \mathrm{l}$ of $0.01 \mathrm{M}$ ONPG prepared in phosphate buffer ( $\mathrm{pH} 6.8,0.1 \mathrm{M}$ ). To every test tubes $250 \mu \mathrm{l}$ of crude enzyme extract and $2 \mathrm{ml}$ of phosphate buffer ( $\mathrm{pH} 6.8,0.1 \mathrm{M}$ ) was added to the test tube and then incubated at $37^{\circ} \mathrm{C}$ for 70 minutes. The reaction was quenched by adding $250 \mu \mathrm{l}$ of $0.5 \mathrm{M} \mathrm{Na}_{2} \mathrm{CO}_{3}$ at every 30 minutes interval and the reaction progress was determined spectrophotometrically at $420 \mathrm{~nm}$ against 
the blank (750 $\mu$ l ONPG, $2250 \mu$ l phosphate buffer of pH 6.8) (Fernandes et al. 2002).

Determination of optimum temperature: 8 test tubes were filled with $750 \mu \mathrm{l}$ of $0.01 \mathrm{M}$ ONPG prepared in phosphate buffer ( $\mathrm{pH} 6.8,0.1 \mathrm{M})$.To every test tubes $250 \mu \mathrm{l}$ of crude enzyme extract and $2 \mathrm{ml}$ of phosphate buffer ( $\mathrm{pH} 6.8,0.1 \mathrm{M}$ ) was added to the test tube and then incubated separately at different temperatures of $0^{\circ} \mathrm{C}, 14^{\circ} \mathrm{C}, 22^{\circ} \mathrm{C}, 27^{\circ} \mathrm{C}, 37^{\circ} \mathrm{C}, 40^{\circ} \mathrm{C}, 45^{\circ} \mathrm{C}$ and $50^{\circ} \mathrm{C}$ for 70 minutes. The reaction was quenched by adding $250 \mu \mathrm{l}$ of $0.5 \mathrm{M} \mathrm{Na}_{2} \mathrm{CO}_{3}$ and the reaction progress was determined spectrophotometrically at $420 \mathrm{~nm}$ against the blank (750 $\mu$ l ONPG, $2250 \mu 1$ phosphate buffer of pH 6.8) (Zhou and Chen 2001).

Determination of optimum pH: Eight test tubes were filled with $750 \mu \mathrm{l}$ of $0.01 \mathrm{M}$ ONPG prepared in phosphate buffer of $\mathrm{pH} 5.5,6.0,6.2,6.4,6.6,6.8,7.0$ and 7.12. To every test tube $250 \mu \mathrm{l}$ of crude enzyme extract and $2 \mathrm{ml}$ of phosphate buffer of respective $\mathrm{pH}$ was added and then incubated at $37^{\circ} \mathrm{C}$ for 70 minutes. The reaction was quenched by adding $250 \mu \mathrm{l}$ of $0.5 \mathrm{M}$ $\mathrm{Na}_{2} \mathrm{CO}_{3}$ and the reaction progress was determined spectrophotometrically at $420 \mathrm{~nm}$ against the blank (750 $\mu \mathrm{l}$ ONPG, $2250 \mu \mathrm{l}$ phosphate buffer of $\mathrm{pH}$ 6.8) (Zhou and Chen 2001).
Determination of $\mathbf{K}_{\mathrm{m}}$ value: Nine test tubes were filled with 50, 100, 150, 200, 250, 300, 350, 400 and 450 $\mu \mathrm{l}$ of $0.01 \mathrm{M}$ ONPG prepared in phosphate buffer of $\mathrm{pH}$ 6.8. Final volume was made $1750 \mu \mathrm{l}$ by addition of phosphate buffer of $\mathrm{pH}$ 6.8. $250 \mu \mathrm{l}$ of enzyme was added to each test tubes and incubated at $37^{\circ} \mathrm{C}$ for 70 $\min$. The reaction was quenched by adding $250 \mu \mathrm{l}$ of $0.5 \mathrm{M} \mathrm{Na}_{2} \mathrm{CO}_{3}$ and the reaction progress was determined spectrophotometrically at $420 \mathrm{~nm}$ against the blank (750 $\mu \mathrm{l}$ ONPG, $1250 \mu \mathrm{l}$ phosphate buffer of $\mathrm{pH}$ 6.8) (Fernandes et al. 2002).

\section{RESULTS}

Isolation of lactose positive yeast strains: Four lactose positive yeast isolates were obtained from the dairy samples. Isolate 1 showing the highest lactose positive activity was taken for further study.

Protein concentration: The protein concentration in extracted and purified enzyme extracts was found to be $0.465 \mu \mathrm{g} / \mu \mathrm{l}(\mathrm{mg} / \mathrm{ml})$ using Bradford assay compared with standard BSA solution.

Effect of incubation time, temperature and $\mathrm{pH}$ on enzyme activity: The enzyme has an optimum incubation time of $70 \mathrm{~min}$ and optimum temperature at $37^{\circ} \mathrm{C}$. Whereas the optimum $\mathrm{pH}$ of enzyme was found to be slightly acidic at 6.8 (Figure 1, 2 and 3).

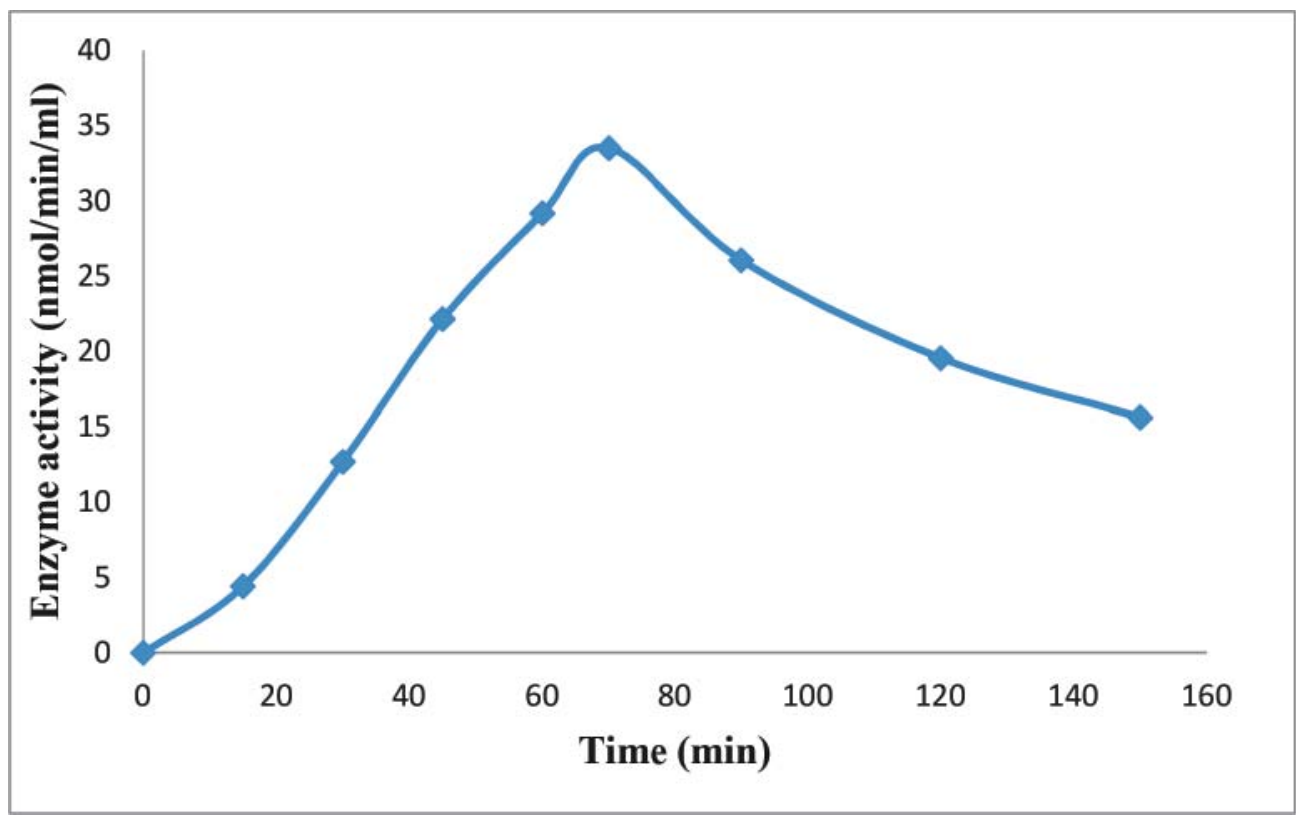

Figure 1: Effect of incubation time on enzyme activity 


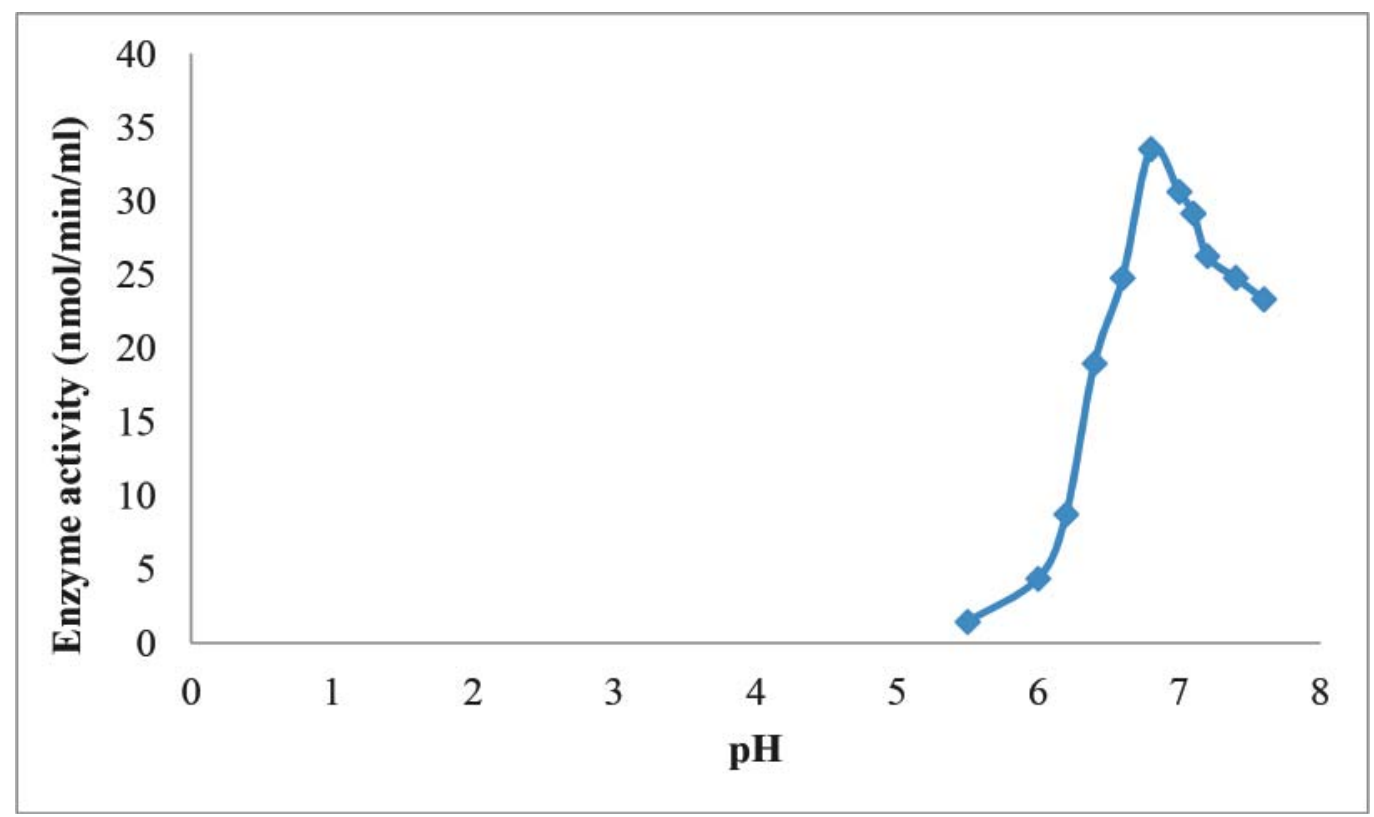

Figure 2: Effect of Temperature on enzyme activity

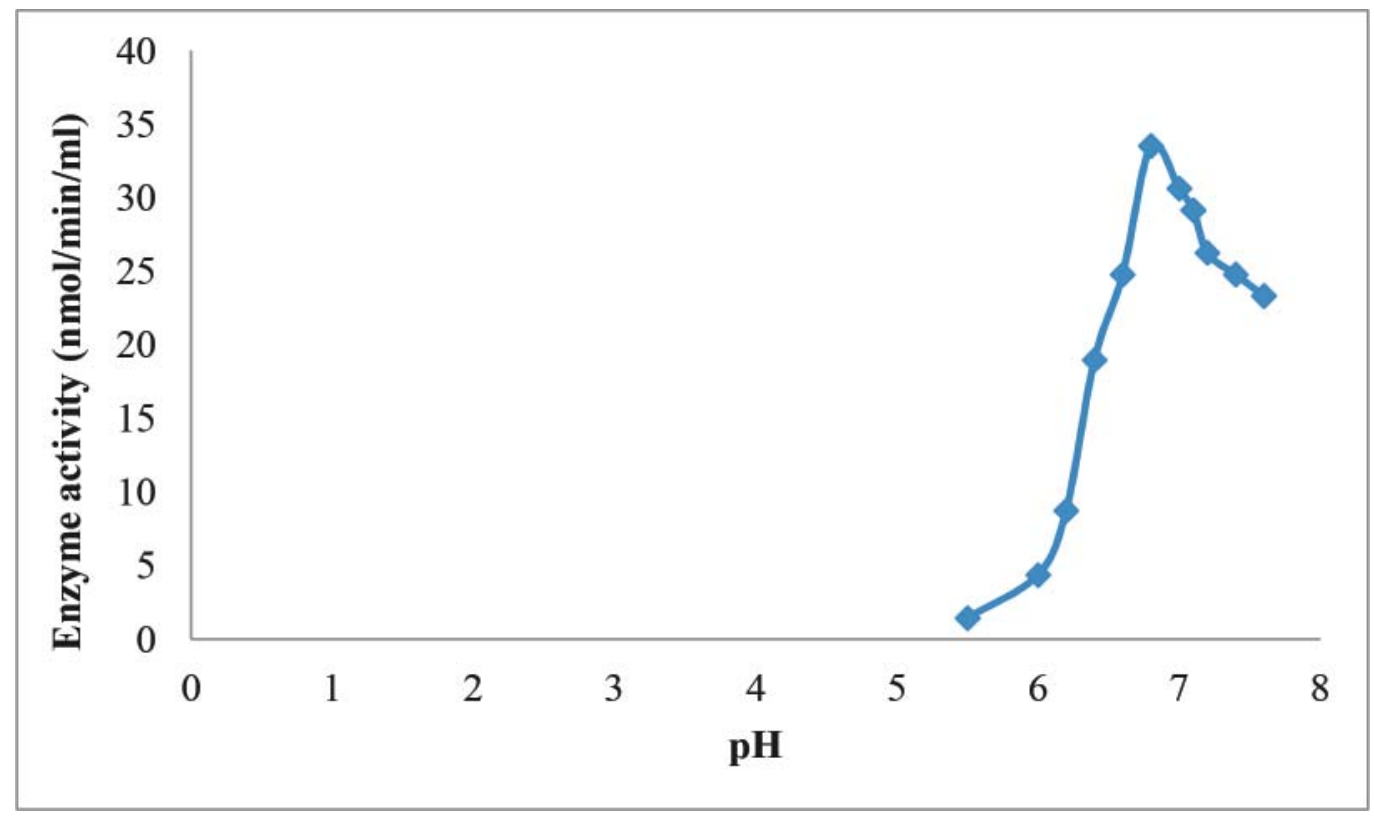

Figure 3: Effect of pH on Enzyme activity

Effect of incubation time, temperature and $\mathrm{pH}$ on specific activity: Like an enzyme activity, highest specific activity of enzyme was observed with $70 \mathrm{~min}$ incubation, at $37^{\circ} \mathrm{C}$ temperature and at $6.8 \mathrm{pH}$ (Table 1). 
Table 1: Effect of incubation time, temperature and $\mathrm{pH}$ on specific activity of enzyme

\begin{tabular}{cccccc}
\hline $\begin{array}{c}\text { Incubation } \\
\text { time }(\mathbf{m i n})\end{array}$ & $\begin{array}{c}\text { Specific activity } \\
(\mathbf{n m o l} / \mathbf{m i n} / \mathbf{m g})\end{array}$ & Temperature (oC) & $\begin{array}{c}\text { Specific activity } \\
(\mathbf{n m o l} / \mathbf{m i n} / \mathbf{m g})\end{array}$ & $\mathbf{p H}$ & $\begin{array}{c}\text { Specific activity } \\
(\mathbf{n m o l} / \mathbf{m i n} / \mathbf{m g})\end{array}$ \\
\hline 0 & 0.00 & 0 & 15.61 & 5.5 & 3.10 \\
15 & 9.53 & 14 & 37.63 & 6.0 & 9.40 \\
30 & 27.33 & 22 & 53.25 & 6.2 & 18.82 \\
45 & 47.63 & 27 & 62.67 & 6.4 & 40.73 \\
60 & 62.75 & 37 & 72.06 & 6.6 & 53.24 \\
70 & 72.06 & 40 & 37.63 & 6.8 & 72.06 \\
90 & 55.94 & 45 & 12.52 & 7.0 & 65.84 \\
120 & 42.01 & 50 & 9.40 & 7.1 & 62.67 \\
150 & 33.61 & & & 7.2 & 56.43 \\
& & & & 7.4 & 53.25 \\
\hline
\end{tabular}

Effect of substrate concentration on enzyme activity: The $\mathrm{V}_{\max }$ and $\mathrm{K}_{\mathrm{m}}$ values of enzymes were determined to $58.82 \mathrm{nmol} / \mathrm{min} / \mathrm{ml}$ and $2.23 \mathrm{mM}$ of ONPG respectively using Lineweaver-Burk plot while $\mathrm{V}_{\max }$ and $\mathrm{K}_{\mathrm{m}}$ values were found to be $54.43 \mathrm{nmol} / \mathrm{min} / \mathrm{ml}$ and $2.036 \mathrm{mM}$ of ONPG respectively using Eadie-Hofstee plot (Table 2, Figure 4 and Figure 5).

Table 2: Effect of substrate Concentration on enzyme activity

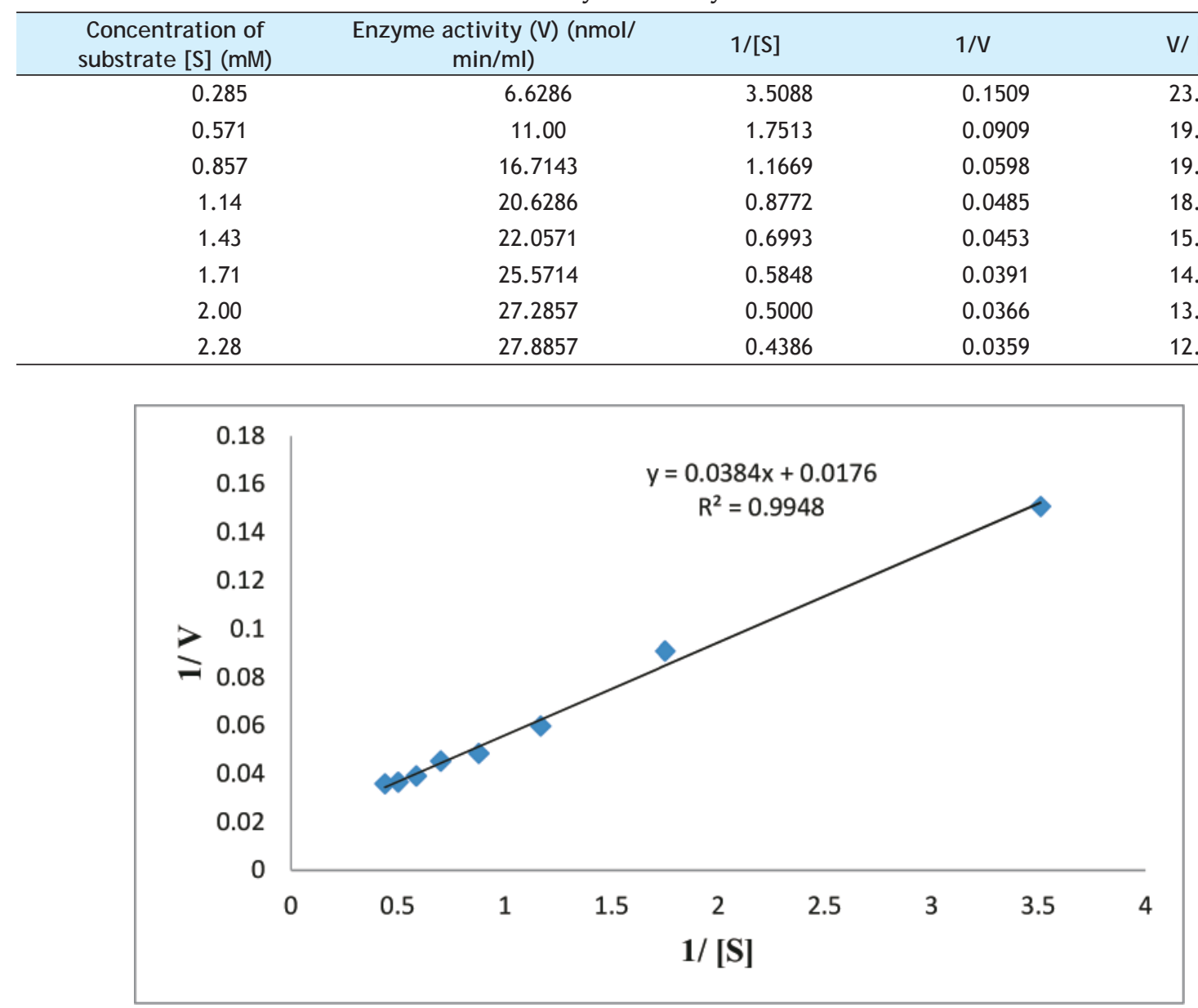

Figure 4: Lineweaver-Burk/Double reciprocal plot 


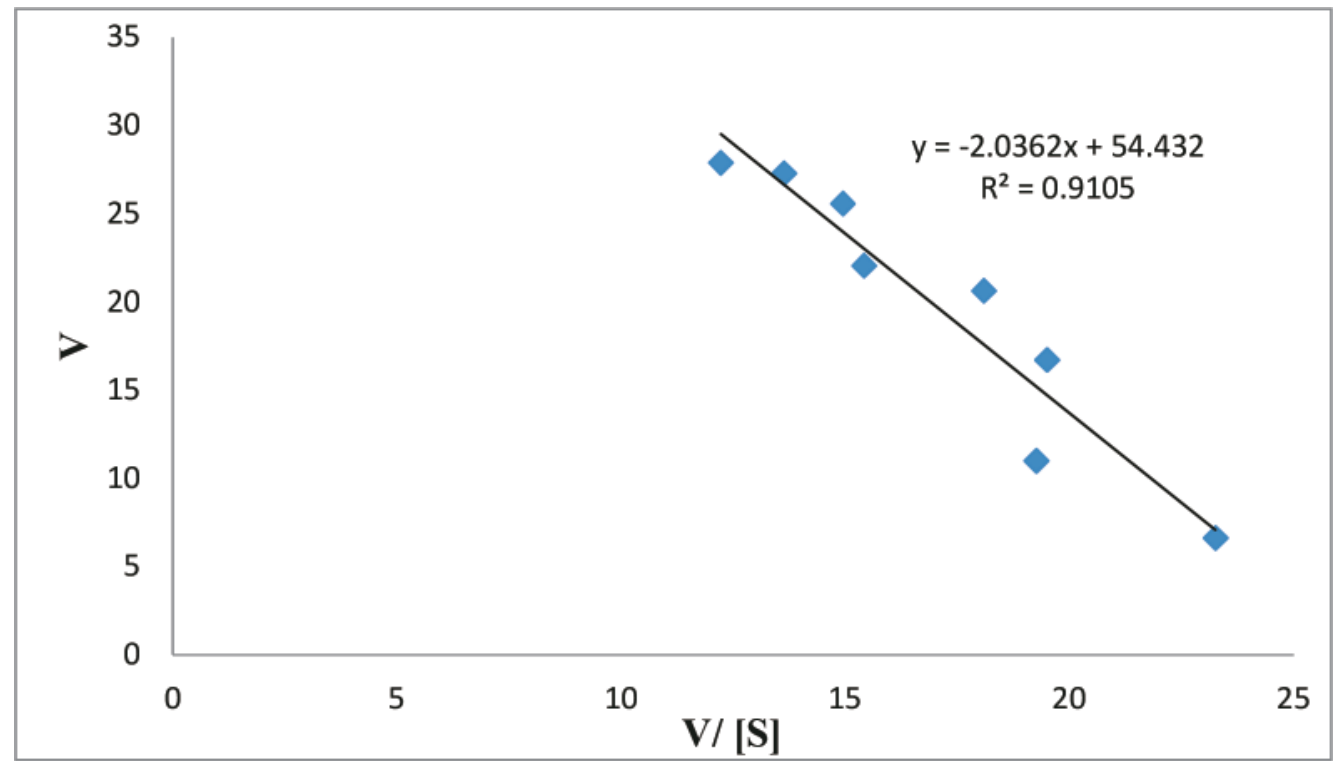

Figure 5: Eadie-Hofstee plot (V/ [S] Vs. V]

Calculation of specific and total enzyme activity: The specific and total enzyme activity were calculated to be $59.97 \mathrm{nmol} / \mathrm{min} / \mathrm{mg}$ and $3346.33 \mathrm{nmol} / \mathrm{min}$ respectively (Table 3).

Table 3: Summary of enzyme characteristics

\begin{tabular}{cc}
\hline Enzyme parameters & Values \\
\hline Protein concentration of enzyme extract & $0.465 \mathrm{mg} / \mathrm{ml}$ \\
Initial volume of enzyme extract & $120 \mathrm{ml}$ \\
Total protein of enzyme extract & $55.8 \mathrm{mg}$ \\
Optimum time & $70 \mathrm{~min}$. \\
Optimum pH & 6.8 \\
Optimum temperature & $37^{\circ} \mathrm{C}$ \\
$\mathrm{K}_{\mathrm{m}}$ & $2.23 \mathrm{mM} \mathrm{of} \mathrm{ONPG}$ \\
$\mathrm{V}_{\text {max }}$ & $58.82 \mathrm{nmol} / \mathrm{min} / \mathrm{ml}$ \\
Enzyme activity & $27.88 \mathrm{nmol} / \mathrm{min} / \mathrm{ml}$ \\
Specific enzyme activity & $59.97 \mathrm{nmol} / \mathrm{min} / \mathrm{mg}$ \\
Total enzyme activity & $3346.33 \mathrm{nmol} / \mathrm{min}$ \\
\hline
\end{tabular}

\section{DISCUSSION}

The knowledge of enzyme stability can provide information on the structure of an enzyme which can aid in the economical industrial production of enzyme. Activity and stability of an enzyme depend upon the spatial conformation of the protein and is affected by various environmental factors such as $\mathrm{pH}$, temperature, reaction medium, presence of ions. It is important to optimize these factors so, as to allow economical industrial production of enzyme. It is also important to determine the enzyme kinetic parameters such as Michaelis-Menten constant $\left(\mathrm{K}_{\mathrm{m}}\right)$, maximum enzyme activity $\left(\mathrm{V}_{\max }\right)$, optimum time duration which are necessary to characterize an enzyme and to optimize the enzymatic process.
The optimum time of reaction was found to be 70 mins. The activity gradually fell beyond 70 mins indicating the inactivation of the enzyme with time. The activity curve for effect of $\mathrm{pH}$ gave a bell-shaped curve with maximum activity in the near neutral $\mathrm{pH}$ of 6.8 . The optimum $\mathrm{pH}$ of 6.8 suggests that the enzyme can be classified as slightly acidic. However, the enzyme showed activity over a wide range of $\mathrm{pH}$ from 5.5-7.6. In general, $\beta$-galactosidase from yeast and bacteria has optimum $\mathrm{pH}$ at near neutral range, whereas the enzyme from molds acts well at more acidic level (Gurr 1987; Sani et al. 1999).

The activity curve of effect of temperature on enzyme activity gave a bell-shaped curve with maximum activity at $37^{\circ} \mathrm{C}$. The enzyme had wide range of 
working temperature from $0-50^{\circ} \mathrm{C}$. However, greater than $50 \%$ hydrolyzing ability was maintained in the range of $14-40^{\circ} \mathrm{C}$. The enzyme even showed slight activity at freezing temperature $\left(0^{\circ} \mathrm{C}\right)$. This shows that the enzyme has potential application for managing the lactose pollution at the normal as well as low ambient temperatures. The enzyme showed least activity at temperatures $45^{\circ} \mathrm{C}$ or greater. This must be due to the denaturation of the enzyme at higher temperatures (Sani et al. 1999; Wolosowska and Synowiecki 2004).

The activity curve for effect of substrate concentration on enzyme activity (Michaelis-Menten plot) showed that at low substrate concentration, almost linear increment in enzyme activity with increase in substrate concentration was seen. But at higher substrate concentration the enzyme activity increased by smaller and smaller amount in response to increases in substrate concentration and almost a plateau like region was seen. The activity/rate of an enzymatic reaction depends upon the concentration of the enzyme substrate [ES] complex. At low substrate concentration most of the enzyme is present in uncombined form [E], so the rate is proportional to substrate concentration. This explains for almost linear increment in enzyme activity with increase in substrate concentration, at low substrate concentration. At high substrate concentration most of the enzyme is present as ES complex i.e. virtually all the active sites in an enzyme are saturated with substrate, so that further increase in substrate concentration doesn't produce an appreciable increment in the enzyme activity. This explains the almost plateau like region observed in the enzyme activity at higher substrate concentration (Pivarnik et al. 1995; Prenosil et al. 1987).

From Lineweaver-Burk plot the $\mathrm{K}_{\mathrm{m}}$ value and $\mathrm{V}_{\max }$ was found to be $2.23 \mathrm{mM}$ of ONPG and $58.82 \mathrm{nmol} / \mathrm{min} /$ $\mathrm{ml}$ respectively. From Eadie-Hofstee plot the $\mathrm{K}_{\mathrm{m}}$ value and $\mathrm{V}_{\max }$ was found to be $2.036 \mathrm{mM}$ of ONPG and $54.43 \mathrm{nmol} / \mathrm{min} / \mathrm{ml}$ respectively. The low $\mathrm{K}_{\mathrm{m}}$ value of the enzyme indicated that the enzyme had high affinity for the substrate ONPG and the substrate is tightly bound to the enzyme (Fernandes et al. 2002).

The protein concentration of the crude enzyme extract was found to be $0.465 \mathrm{mg} / \mathrm{ml}$. The low protein concentration and the high enzyme activity indicated that the enzyme $\beta$-galactosidase comprised most of the protein fraction of the crude enzyme extract. It might be due to the induction of $\beta$-galactosidase as a result of high lactose content of mass culture broth (YEP broth).

\section{CONCLUSION}

The enzyme was slightly acidic (near neutral $\mathrm{pH}$ ) and showed maximum activity at $37^{\circ} \mathrm{C}$ but showed activity over a wide range of temperature $0-50^{\circ} \mathrm{C} . \mathrm{K}_{\mathrm{m}}$ value of the enzyme was $2.23 \mathrm{mM}$ of ONPG, thus the enzyme has high affinity for ONPG. The overall properties of enzyme showed the potential use of the enzyme as industrial application.

\section{ACKNOWLEDGEMENTS}

We would like to express our sincere gratitude to all staff of Research Laboratory for Biotechnology and Biochemistry (RLABB), Kathmandu for their support throughout the research work.

\section{CONFLICT OF INTEREST}

The authors declare that they have no competing interests.

\section{REFERENCES}

Amir E and Whorwell PJ (2009) Lactose and Fructose intolerance. Allergy Frontiers: clinical Manifestation 3: 431-447.

Barnett JA, Yarrow D and Payne RW (1990) The yeasts: Classification and identification. $2^{\text {nd }} \mathrm{Ed}$., Cambridge University Press. pp 50-77.

Bradford MM (1976) A rapid and sensitive method for the quantitation of microgram quantities of protein utilizing the principle of protein-dye binding. Anal Biochem 72: 248-254

Cantarel BL, Coutinho PM, Rancurel C, Bernard T, Lombard V and Henrissat B (2009) The Carbohydrate-Active Enzymes database (CAZy): an expert resource for glycogenomics. Nucl. Acids Res 37: D233- 238.

El-Kader ASSA, El-Dosouky MA, Abouwarda, A, AbdelAll ISM and Osman MI (2012) Characterization of partially purified $\beta$-galactosidase from Bacillus subtilis. Journal of applied sciences research 8(4): 2379-2385.

Fernandes S, Geueke B, Delgado O, Coleman J and Hatti-Kaul R (2002) $\beta$ galactosidase from a coldadapted bacterium: purification, characterization and application for lactose hydrolysis. Applied Microbiology and Biotechnology 58: 313-321. 
Gurr MI (1987) Nutritional aspects of fermented milk products. FEMS Microbiology Reviews 46: 337-342.

Harju M (1987) Lactose hydrolysis. Bulletin of International Dairy Federation 212: 50-54.

Hinz SW, van den Boek LAM, Beldman G, Vincken JP and Voragen AGJ (2004) $\beta$-Galactosidase from Bifidobacterium adolescentis DSM20083 prefer $\beta(1,4)$-galactosides over lactose. Appl Microbiol Biotechnol 66: 276-284.

Husain Q (2010) $\beta$ Galactosidases and their potential applications: a review. Critical Reviews in Biotechnology 30(1): 41-62.

Johnson A, Semenya JG, Buchowski MS, Enwonwu CO and Scrimshaw NS (1993) Correlation of lactose maldigestion, lactose intolerance and milk intolerance. American Journal of Clinical Nutrition 57: 199-401.

Kara F (2004) Release and Characterization of Betagalactosidase from Lactobacillus plantarum. M.Sc. Thesis, Middle East Technical University, Turkey.

Mahoney RR (1998). Galactosyl-oligosaccharide formation during lactose hydrolysis: a review. Journal of Food Chemistry 63: 147-154.

Miller JN and Whistler RL (2000) Carbohydrates, New York: Marcel Dekker.

Nahvi I and Moeini H (2004) Isolation and identification of yeast strains with high beta-galactosidase activity from dairy products. Biotechnology 3: 3540 .

Pivarnik LF, Senacal AG and Rand AG (1995) Hydrolytic and transgalactosylic activities of commercial $\beta$-galactosidase (lactase) in food processing. Advances in Food and Nutrition Research 38: 1-102.

Prenosil, JE, Stuker E and Bourne JR (1987) Formation of oligosaccharides during enzymatic lactose hydrolysis and the importance in a whey hydrolysis process: part II experimental. Biotechnol Bioeng 30: 1026-1031.

Rabiu BA, Jay AJ, Gibson GR and Rastall RA (2001) Synthesis and fermentation products of novel galacto- oligosaccharides by $\beta$-galactosidases from Bifidobacterium species. Appl Environ Microbiol 67: 2526-2530.

Sako T, Matsumoto K and Tanaka R (1999) Recent progress on research and applications of nondigestible galacto-oligosaccharides. Int. Dairy J 9: 69-80.

Sani RK, Chakraborti S, Sobti RC, Patnaik PR and Banerjee UC (1999) Characterization and some reaction-engineering aspects of thermostable extracellular $\beta$-galactosidase from a new Bacillus species Folia Microbiol 44(4): 367-371.

Santos A, Ladero M and Garcia-Ochoa F (1998) Kinetic modelling of lactose hydrolysis by a $\beta$-galactosidase from Kluyveromyces fragilis. Enzyme and Microbial Technology 22: 558-567.

Sears P and Wong CH (2001) Toward automated synthesis of oligosaccharides and glycoproteins, Science 291: 2344-2350.

Shipkowski S and Brenchley JE (2006) Bioinformatic, genetic, and biochemical evidence that some glycoside hydrolases family $42 \beta$-galactosidase are arabinogalactan type I oligomer hydrolases. Appl Environ Microbiol 72: 7730-7738.

Suarez FL and Savaiano WA (1997) Diet, genetics, and lactose intolerance. Food Technology 51: 74-76.

Wierzbicki LE and Kosikowski FV (1973) Food syrups from acid whey treated with/3-galactosidase of Aspergillus niger. J Dairy Sci 56: 1182.

Wolosowska S and Synowiecki J (2004) Thermostable $\beta$-glucosidase with a broad substrate specificity suitable for processing of lactose-containing products. Food Chemistry 85: 181-187.

Zadow JG (1992) Whey and lactose processing. In: Zadow, J. G. (Ed.): London and New York: Elsevier Applied Sciences 489, ISBN 1-8516-6753-9.

Zhou QZK and Chen XD (2001) Effects of temperature and $\mathrm{pH}$ on the catalytic activity of the immobilized $\beta$-galactosidase from Kluyveromyces lactis. Biochemistry and Engineering Journal 9: 33-40. 